\title{
Real-Time Implementation of a Super Twisting Algorithm for PEM Fuel Cell Power System
}

\author{
Mohamed Derbeli ${ }^{1,2, *(1)}$, Oscar Barambones ${ }^{1}$ (i), Jose Antonio Ramos-Hernanz ${ }^{1}$ (1) \\ and Lassaad Sbita ${ }^{2}$ \\ 1 Engineering School of Vitoria, University of the Basque Country UPV/EHU, Nieves Cano 12, \\ 1006 Vitoria, Spain; oscar.barambones@ehu.es (O.B.); josean.ramos@ehu.eus (J.A.R.-H.) \\ 2 National Engineering School of Gabes, University of Gabes, Omar Ibn-Elkhattab, Zrig, 6029 Gabes, Tunisia; \\ lassaad.sbita@gmail.com \\ * Correspondence: derbelimohamed1@gmail.com; Tel.: +34-617-916-276 or +216-54-104-924
}

Received: 31 March 2019; Accepted: 20 April 2019; Published: 26 April 2019

\begin{abstract}
Proton exchange membrane fuel cell (PEMFC) topology is becoming one of the most reliable and promising alternative resource of energy for a wide range of applications. However, efficiency improvement and lifespan extension are needed to overcome the limited market of fuel cell technologies. In this paper, an efficient approach based on a super-twising algorithm (STA) is proposed for the PEMFC system. The control objective is to lengthen the fuel cell lifetime by improving its power quality, as well as to keep the system operating at an optimal and efficient power point. The algorithm adjusts the PEMFC operating point to the optimum power by tuning the duty cycle of the boost converter. The closed-loop system includes the Heliocentris hy-Expert ${ }^{\mathrm{TM}}$ PEMFC, DC-DC boost converter, DSPACE DS1104, dedicated PC, and a programmable electronic load. The practical implementation of the proposed STA on a hardware setup is performed using a dSPACE real-time digital control platform. The data acquisition and the control system are conducted together with the dSPACE 1104 controller board. To demonstrate the performance of the proposed algorithm, experimental results are compared with 1-order sliding mode control (SMC) under different load resistance. The obtained results demonstrate the validity of the proposed control scheme by ensuring at least $72 \%$ of the maximum power produced by PEMFC. In addition, it is proven that the STA ensures all the fundamental properties of the 1-order SMC, as well as providing chattering reduction of $91 \%$, which will ameliorate as a consequence the fuel cell lifetime.
\end{abstract}

Keywords: DC-DC Boost converter; dSPACE controller board; PEMFC; super twisting algorithm

\section{Introduction}

At present, the entire world is becoming aware of the problems derived from traditional energies such as fossil fuels and non-renewable energies which have destructive environmental impacts. On the other hand, the ever-increasing energy demand and rising crude oil prices, as well as predictable expiration of fossil fuels reserves, have also caused high ambitions toward renewable and sustainable energy resources. In this context, renewable energy sources (RES) such as wind and solar are considered as suitable and viable alternative options to generate electrical power [1-5]. However, despite the environmental friendly features of these energies, their dependency on the weather conditions is still a considerable obstacle. Thus, the solar energy is lower in winter months and cloudy days below, as it is only available during the daytime. On the other hand, the wind energy is only available when the wind blows.

Due to its low amount of contamination, its abundance on the Earth's surface, as well as its high volatility and efficiency, hydrogen has been chosen as the most suitable alternative fuel to traditional 
fossil fuels. It could replace fossil fuels in the automotive sector (with properly modification in the motor), or also could be used with oxygen in fuel cells to produce electricity. Thereby, proton exchange membrane fuel cells (PEMFCs), which have hydrogen as fuel, are considered as some of the most reliable and promising energy conversion devices. They can provide a continuous power supply throughout all seasons as long as fuel is provided. Moreover, unlike internal combustion engines, fuel cells are not combusted, the energy instead is produced through a chemical reaction. This results in several benefits such as high efficiency, low maintenance, and quiet operation. Thus, for the same quantity of fuel, fuel cells can extract $90 \%$ more efficient power than traditional gasoline. Fuel cells are also very simple in maintenance since they have no moving parts in their construction. In addition, the absence of mechanical parts in their composition allows them to operate silently. PEMFCs have many advantages not only when compared with traditional fossil fuels, but also even when compared with other types of cells. They are characterized by their low operating temperature, fast electrochemical reaction (quick start up), low cost, which is a very important point, long cycle life and their high power density [6-8]. Therefore, PEMFCs are ideally suited for a wide range of applications, such as stationary, automotive, and portable power supplies. However, despite the sundry features of the PEMFCs, cost reduction and efficiency improvement are needed to overcome the limited market of fuel cells' technologies $[9,10]$. The high cost of PEMFCs may have been the fundamental hindrance in the past, but with the development of technology, this may have not been the case. Therefore, it is necessary to overcome other specific barriers such as: low efficiency with output ripple current, low output voltage that decreases as the load current increases and limited overload capability. To overcome these specific challenges, power converters with a control strategy are usually required to step up and regulate the output voltage to provide an appropriate DC power source that may be used for various applications [11-15].

To date, over 800 different topologies of DC-DC converters have been developed [16]. The advantages and disadvantages of each topology are discussed in [16-18]. They can be used to transform the power with boosting or bucking the output voltage, which is controlled by the pulse width modulation (PWM) switching technique. Due to their higher efficiency in comparison with other converters' topologies, buck, boost and back boost converters have been chosen as the most commonly used in a wide range of applications. These converters are characterized by a few component counts, which results in a reduction in the conduction losses. In this work, due to the low voltage of the PEMFCs, a DC-DC boost converter is used to step-up and regulate the generated DC voltage. In addition, in order to improve and optimise the dynamic response and efficiency of the overall system, a reliable digital controller that ensures stability is used to control the PWM generator, which feeds the DC-DC converter $[9,11]$.

During the last few decades, many control strategies are proposed for PEM fuel cell power systems. Traditional controllers such as proportional-integral (PI) and proportional-integral derivative (PID) control are widely used in the literature. Thus, Choe [19] used PID control for a DC-DC boost converter with a fuel cell dynamic model. Andujar [20] used a small signal model with a linearized PEMFC model for controlling the DC-DC converter, given that the parameters of the controller should be changed for any variation in the operating conditions. Authors of [21] used a PI control to keep the PEMFC working in an efficient power point. In [22], Habib developed a genetic algorithm (GA) based on a linear quadratic regulator (LQR) to regulate the PEMFC terminal voltage. Obtained results show that chattering reduction of $84 \%$ could be achieved using the proposed algorithm. However, the linear control of DC-DC converter is not suitable for PEMFC application. To overcome this issue, many robust control approaches have been developed to cope with nonlinearity and ensure stability. In [23], Huang demonstrated experimentally that the efficiency of the fuel cell can be improved from $14.67 \%$ when using a conventional PID controller to $37 \%$ when using a fuzzy controller. However, some oscillations are accrued in the electrical characteristics, which may cause serious life-shortening and severe cell deterioration. In [24], chattering reduction of $70.93 \%$ is achieved using an advanced variable step-size fuzzy logic control (FLC). Kim [25] and Samosir [26] used a dynamic evolution 
control (DEC) to achieve an accurate duty cycle control for energy storage in a hybrid fuel cell system. A comprehensive study of SMC implementation in a PEMFC power system is addressed in [27]. The control process is performed using first order SMC, which applied to a DC-DC buck converter in order to ensure low and stable output voltage. Several platforms of the $H \infty$ controller for the PEMFC are investigated in [28]. Wang concluded that an efficiency improvement of $1.4 \%$ and a reduction of $93 \%$ in the root-mean-square error (RMSE) of the PEMFC voltage could be obtained. In addition, he concluded that this controller can be implemented on different modules without any modification taking into account that the resulting controller is only optimal in the predefined cost function and its performance in other aspects is not guaranteed. Rezazadeh [29] designed an adaptive inverse controller, known as radial basis function neural network (RBFNN), for the PEMFC system. This control scheme did not require any parameter identification of the system, which means that the needed experimental data for the control design can be reduced. In [30], to obtain an accurate controller, feedback linearization control applied to a PEMFC power system was optimized via a non-dominated sorting genetic algorithm II (NSGA-II). The optimization process was performed on the linear gains of the designed controller. Recently, authors of [31] have developed a super-twisting algorithm (STA) in order to optimize the produced power of the PEMFC. According to their results, the simplicity of the control scheme, robustness and high accuracy can be highlighted even with the presence of model uncertainties and large load variations. However, despite the good results obtained in [29-31] for PEMFC improvement, only simulation studies have been presented.

This paper is focused on validation of a previous study which was presented in [31]. The main aim of this work is to validate the performance of the STA applied to a DC-DC boost converter in order to keep the PEMFC operating at an efficient power point. This last aim is currently the least studied aspect of control of fuel cells, but also one of its most important issues. Therefore, in order to address this issue, a hardware system is realized with a FC50 fuel cell stack, DC-DC boost converter, and dSPACE real-time digital control platform. The data acquisition and the control system are conducted all around the dSPACE 1104 controller board environment.

This work has been organized as follows: the PEMFC model has been reviewed in Section 2. In Section 3, the power electronic interface has been presented. A description of the experimental system has been described in Section 4. Section 5 presents the experimental results obtained with a FC50 fuel cell stack. Finally, some conclusions have been pointed out in Section 6.

\section{PEMFC Modeling and Analysis}

A PEMFC is used as a power supply source for a fuel cell power system. It is an electrochemical device that combines chemical energy to produce electricity, as well as water and heat as its by-product. A PEMFC uses air or pure oxygen $\left(\mathrm{O}_{2}\right)$ as the oxidant and hydrogen $\left(\mathrm{H}_{2}\right)$ as the fuel gas. Figure 1 shows a schematic diagram of the PEMFC, which consists of an electrolyte membrane placed between two electrodes (anode and cathode) that are coated with the platinum catalyst [32-34]. The electrolyte membrane plays a key role; it allows only the appropriate ions $\left(\mathrm{H}^{+}\right)$to flow between the anode and cathode. The $\mathrm{H}_{2}$ gas, extracted using a reformer from the hydrocarbon fuel $\left(\mathrm{C}_{n} \mathrm{H}_{2 n+2}\right)$, is supplied at the anode. Air, a source of $\mathrm{O}_{2}$, is supplied at the cathode. At the anode, in the presence of platinum catalyst, $\mathrm{H}_{2}$ is ionized into positively charged hydrogen ions $\left(\mathrm{H}^{+}\right)$and negatively charged electrons $\left(e^{-}\right)$. Then, $H^{+}$move towards the cathode through the electrolyte membrane, while $e^{-}$flow to the cathode via the external circuit to provide electricity along the way. At the cathode, the $\mathrm{O}_{2}$ reacts with $H^{+}$and $e^{-}$to produce water and heat $[35,36]$. The electrochemical reactions occurring in the anode and cathode, as well as the overall electrochemical reaction of the PEMFC, are respectively described in Equations (1)-(3) [37]:

$$
\begin{gathered}
\mathrm{H}_{2} \Longrightarrow 2 \mathrm{H}^{+}+2 e^{-} \\
2 \mathrm{H}^{+}+\frac{1}{2} \mathrm{O}_{2}+2 e^{-} \Longrightarrow \mathrm{H}_{2} \mathrm{O}
\end{gathered}
$$




$$
\mathrm{H}_{2}+\frac{1}{2} \mathrm{O}_{2} \Longrightarrow \mathrm{H}_{2} \mathrm{O}+\text { Energy. }
$$

The energy obtained by Equation (3) is called the enthalpy of formation $\triangle H=-285.84 \mathrm{~kJ} \cdot \mathrm{mol}^{-1}$, which referred to the higher heating value $(\mathrm{HHV})$ when the water is in liquid form. It can be divided into thermal energy, represented by specific entropy $\triangle S \mathrm{~kJ} \cdot \mathrm{mol}^{-1} \cdot \mathrm{K}^{-1}$, multiplied by the thermodynamic system temperature $T$, and the Gibbs free energy $\triangle G \mathrm{~kJ} \cdot \mathrm{mol}^{-1}$, which represents the work made by the movement of electrons in the external circuit. Therefore, the total energy as given in [38] is:

$$
\triangle H=\triangle G+T \cdot \triangle S \text {. }
$$

The electric work $\triangle G$ is defined by the electric charge $Q$ across the open circuit fuel cell voltage $E$, where $Q$ can be calculated by multiplying the number of electrons $n$ participating in the reaction with the Faraday constant $F$, which represents the electric charge of one mole of electrons $\left(F=96485 \mathrm{C} \cdot \mathrm{mol}^{-1}\right)$ :

$$
\triangle G=-Q \cdot E=-2 \cdot F \cdot E
$$

The values of $\triangle H, \triangle G$, and $\triangle S$ are negative due to the exothermic of the reaction (gives energy). Therefore, the potential given by the PEMFC can be calculated as:

$$
E=-\frac{\triangle H-T \cdot \triangle S}{2 \cdot F} .
$$

$\triangle G$ also depends on the reactants. Therefore, their values can be calculated using the following expression:

$$
\triangle G=\triangle G^{0}-R T\left[\ln \left(P_{H 2}\right)+\frac{1}{2} \ln \left(P_{\mathrm{O} 2}\right)\right],
$$

where $R=8.3143 \mathrm{~J} \cdot \mathrm{mol}^{-1} \cdot \mathrm{K}^{-1}, \triangle G^{0}$ is the change in $\triangle G$ at the standard state pressure (1 atm), and $P_{\mathrm{O} 2}$ and $P_{\mathrm{H} 2}$ represents, respectively, the oxygen and hydrogen partial pressures. Therefore, the PEMFC potential is expressed as:

$$
E=-\frac{\Delta G^{0}}{2 F}+\frac{R T}{2 F}\left[\ln \left(P_{H 2}\right)+\frac{1}{2} \ln \left(P_{O 2}\right)\right]
$$

The term $\frac{\triangle G^{0}}{2 \cdot F}$ varies with temperature and differs from 1.229 (its value at standard state) according to the following expression:

$$
-\frac{\Delta G}{2 F}=1.229+(T-298)\left(\frac{\Delta S^{0}}{2 F}\right) .
$$

By applying the standard thermodynamical relations, which were developed in [39], Equation (8) can be written as:

$$
E=1.229-0.85 \cdot 10^{-3}(T-298)+4.3 \cdot 10^{-5} \times T\left[\ln \left(P_{H 2}\right)+\frac{1}{2} \ln \left(P_{\mathrm{O} 2}\right)\right] .
$$

This potential gives a value of about $1.2 \mathrm{~V}$ for a cell operating at about $25^{\circ} \mathrm{C}$. However, when a fuel cell is made and put to use, it is found that its voltage is often less than the theoretical value. Figure 2 shows the difference between the actual operating voltage and the "no loss" value (ideal voltage) of a typical single cell. The key points to notice about this graph are as follows: an important voltage drop at low currents, the voltage then decreases slowly and more linearly, and finally another important and sharp voltage drop at high currents. This voltage difference is a result of some losses including polarization and interconnection losses between cells. However, according to Larminie [39], the main losses that occur in a fuel cell are activation, ohmic, and concentration polarization losses. The activation losses $V_{a c t}$ are important at low currents and they occur due to the sluggishness of the reactions. The ohmic losses $V_{\text {ohm }}$ occur due to the resistances of the electrolyte and the electrodes 
which respectively hinder the transport of $H^{+}$and $e^{-}$. The concentration losses $V_{\text {conc }}$ occur due to the fluctuation in concentration of reactants. The behavior of each polarization loss is clearly described in Figure 2, and their relationship with current density are respectively expressed in Equations (11)-(13):

$$
\begin{gathered}
V_{\text {act }}=\xi_{1}+\xi_{2} \cdot T+\xi_{3} \cdot T \cdot \ln \left(C_{O 2}\right)+\xi_{4} \cdot T \cdot \ln (I), \\
V_{\text {ohm }}=I \cdot\left(R_{m}+R_{c}\right), \\
V_{\text {con }}=-B \times \ln \left(1-\frac{J}{J_{\text {max }}}\right),
\end{gathered}
$$

where $\xi_{1}, \xi_{2}, \xi_{3}, \xi_{4}, C_{O 2}, R_{m}, R_{c}, B$ and $J_{\max }$ are developed and calculated in [31].

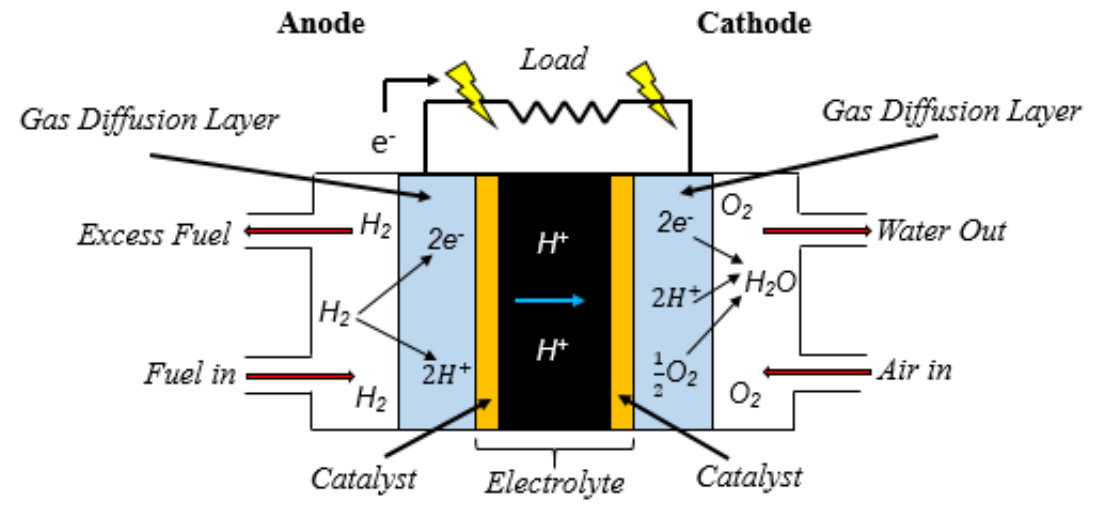

Figure 1. Fuel cell operation diagram.

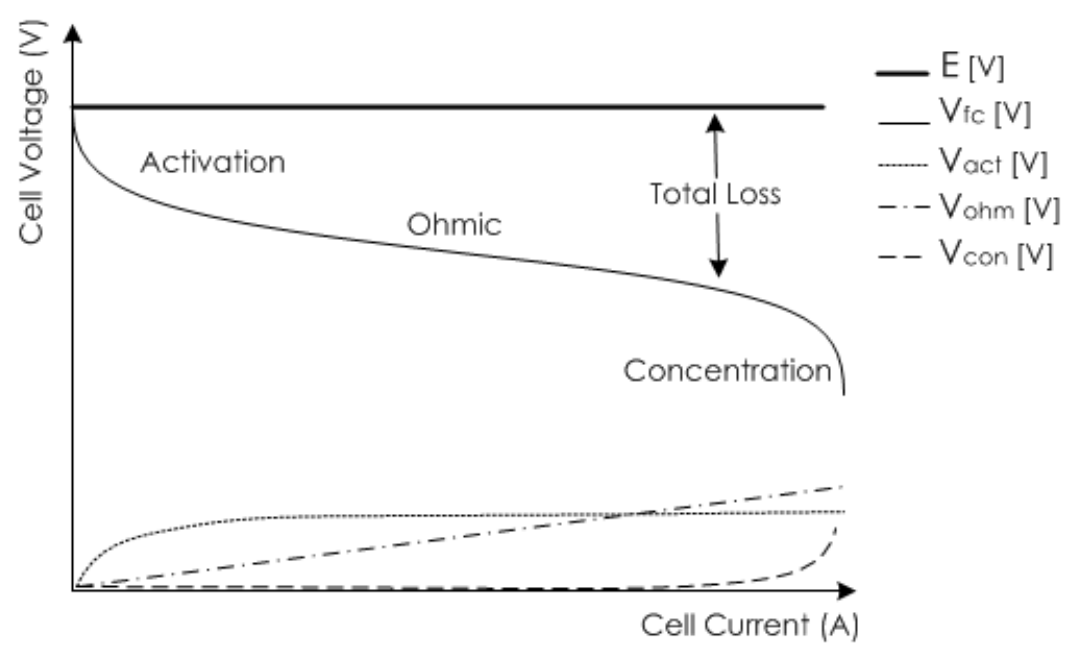

Figure 2. Ideal and actual fuel cell voltage/current characteristics.

Additionally, the fuel cell potential varies with fuel crossover and internal currents due to the waste of fuel and electron conduction through the electrolyte. However, these internal currents and fuel losses are very small and their effects are usually negligible. Therefore, according to [31], the voltage generated by a simple fuel cell can be expressed as:

$$
V_{f c}=E-V_{a c t}-V_{o h m}-V_{c o n} .
$$

The nominal voltage of an individual cell $\left(V_{f c}\right)$ is approximately in the range of 0.8 and 1 volts. Therefore, in order to get a high potential, multiple unit cells (n) are stacked and connected in a series 
form. These n series cells will together produce the total voltage of the stack, which is called $V_{\text {stack }}$. By using the above equations, the model of the PEMFC stack unit can be introduced as Figure 3.

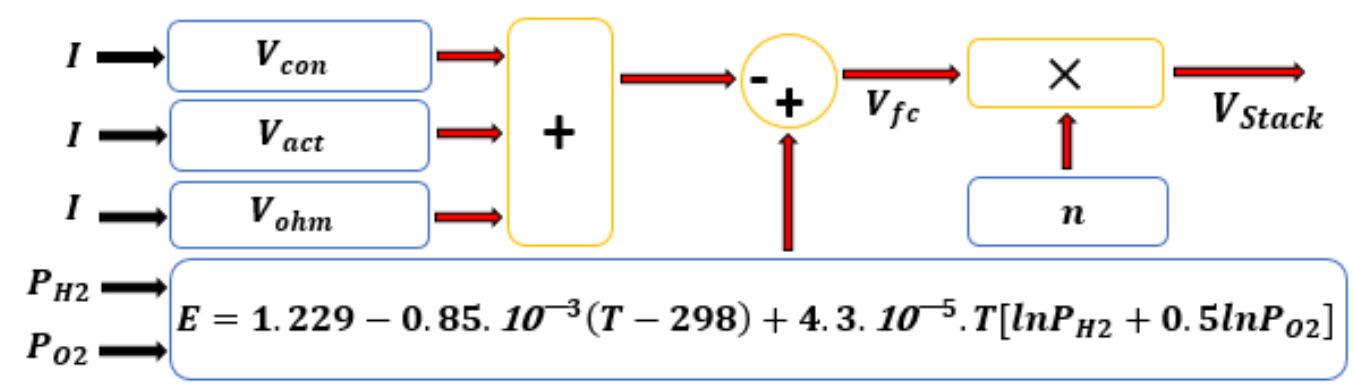

Figure 3. Fuel cell stack model.

\section{Power Electronic Interface}

\subsection{DC-DC Boost Converter}

Taking into account the characteristics of the voltage curve presented in Figure 2, the unregulated output voltage can not be directly linked to the DC bus. Therefore, the application of a DC-DC power electronic converter circuit is mandatory in order to get an applicable voltage for end user applications. Among the DC-DC power electronic converters, the efficiency of the conventional boost converter is always greater than the other converter topologies due to its reduced component count and its simplicity in control. Basically, a boost converter consists of an inductor $(L)$ for energy storage, a switching element $(S)$, a capacitor $(C)$ to reduce the ripple and a diode $(D)$ to isolate the output stage when the switch is on. The choice of the components (inductor, capacitor) value is very important to decrease the ripple generation. It should be noted that, at large inductance, the start-up time could be slightly boosted, while at small inductance, higher levels of current could be reached before the switch turns off [40]. By varying the duty cycle $d_{c}$, the switching element change its state between "on" and "off" to finally obtain the desired regulated voltage. During the "on" state of the switching element, the input current flows through the inductor $L$ and switch $S$. Hence, electrical energy is stored in the inductor, and then the capacitor supplies current to the load and the diode with a reverse bias. When the switch is open, "off" state, the stored energy is transferred to the load and capacitor $C$ through the diode $D$ [41]. The boost converter has two fundamentally different modes of operation, continuous-conduction-mode (CCM) and discontinuous-conduction-mode (DCM). In the CCM, the current in the energy transfer inductor is always greater than zero throughout the switching period, whereas it falls to zero after each switching cycle when in DCM. Furthermore, in DCM, the voltage is influenced by the duty ratio of the switching element and by the load which results more complicity in the DC analysis of the converter. Therefore, in this work, the boost converter and its control are designed based on CCM. The closed loop system including the PEMFC, the DC-DC boost converter, the load, and the controller is shown in Figure 4.

The boost converter state-space representation is expressed in Equation (15):

$$
\left\{\begin{array}{l}
\dot{x}=\left[\begin{array}{cc}
0 & \frac{d_{c}-1}{L} \\
\frac{1-d_{c}}{C} & -\frac{1}{R C}
\end{array}\right] x+\left[\begin{array}{c}
\frac{1}{L} \\
0
\end{array}\right] V_{\text {stack }}, \\
y=\left[\begin{array}{ll}
0 & 1
\end{array}\right] x
\end{array}\right.
$$

where $x=\left[\begin{array}{l}x_{1} \\ x_{2}\end{array}\right], x_{1}=I$ : converter input current, and $x_{2}=V_{\text {out }}$ : converter output voltage. 


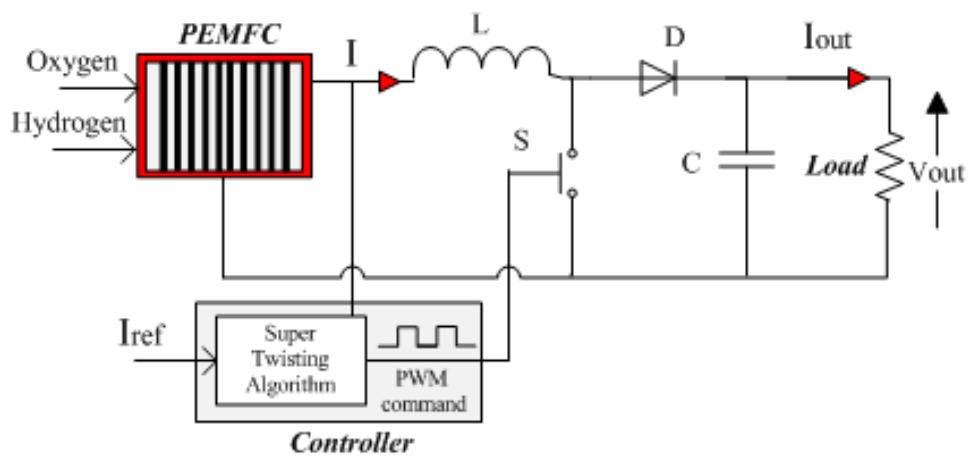

Figure 4. Synoptic diagram of a PEM fuel cell power system.

\subsection{Super-Twisting Algorithm STA}

Super-twisting algorithm (STA) is one of the most powerful 2-order continuous SMC, which ensures all fundamental properties of its traditional 1-order together with chattering reduction [42]. In other words, it is not only robust against system uncertainties and external disturbances, but also has the ability to track the system with high accuracy. It was proposed in 1993 by Professor Levant for systems with a relative degree equal to 1 [43]. Unlike other 2-order SMC algorithms, STA requires only the knowledge of the sliding variable and it does not need any information about its time derivative. This leads to make it a relatively straightforward control law, and, therefore, it is one of the most preferable algorithms for a wide range of applications. In this work, the STA has been applied to drive the converter with the purpose of keeping the PEMFC operating at an efficient power point. The control solution, as shown in Figure 4, directly tackles the stack current through a STA to generate the control signal $u(t)$ for the switch $S$ after treating the sliding mode surface $s(x)$ (namely, the error between the reference current $I_{r e f}$ and the measured inductor current $I$ ). Since STA belongs to the 2-order sliding mode approach, therefore the control signal $u(t)$ can be written as:

$$
u=u_{e q u}+u_{d}
$$

The equivalent control $u_{e q u}$ is a continuous function proposed by slotine in [44]. The main purpose of this function is to ensure that the system reaches the sliding surface $(s=0)$. $u_{\text {equ }}$ was developed to drive the system without considering its uncertainties and external disturbance, and it can be obtained by zeroing $\dot{s}(\dot{s}=0)$. The switching control $u_{d}$ is a discontinuous function which contains the switching element. The main purpose of this function is to ensure the convergence of the overall system by keeping it moving onto the sliding surface. Moreover, it guarantees the robustness against uncertainties and external disturbances. In this work, $u_{d}$ is designed based on STA as given in Equation (17) [45]. It is composed of two parts: a discontinuous part $u_{1}$ and a continuous part $u_{2}$ :

$$
\begin{gathered}
u_{d}=u_{1}+u_{2}, \\
u_{1}=-\lambda \cdot|S|^{1 / 2} \cdot \operatorname{sign}(s), \\
\dot{u}_{2}=-\gamma \cdot \operatorname{sign}(s),
\end{gathered}
$$

where $\lambda$ and $\gamma$ are designed parameters. They can be obtained using the sufficient conditions that are required to ensure the convergence:

$$
\left\{\begin{array}{l}
\gamma>\frac{\Phi}{\Gamma_{m}} \\
\lambda>\sqrt{\frac{2}{\Gamma_{m}^{2}} \cdot \frac{\left(\Gamma_{m} \cdot \gamma+\Phi\right)^{2}}{\left(\Gamma_{m} \cdot \gamma-\Phi\right)}} .
\end{array}\right.
$$


Accordingly, the overall command law of the STA can be obtained as given in Equation (19). On the other hand, the implementation of this command law in MATLAB/Simulink ${ }^{\mathrm{TM}}$ is clearly presented in Figure 5:

$$
u=\frac{V_{\text {out }}-V_{\text {stack }}}{L}-\lambda|S|^{0.5} \operatorname{sign}(S)-\int \gamma \cdot \operatorname{sign}(S) d t .
$$

Trajectories on the 2-sliding plane are characterized by bending around the origin. Thus, as shown in Figure 6, they perform an infinite number of rotations while converging to the origin.

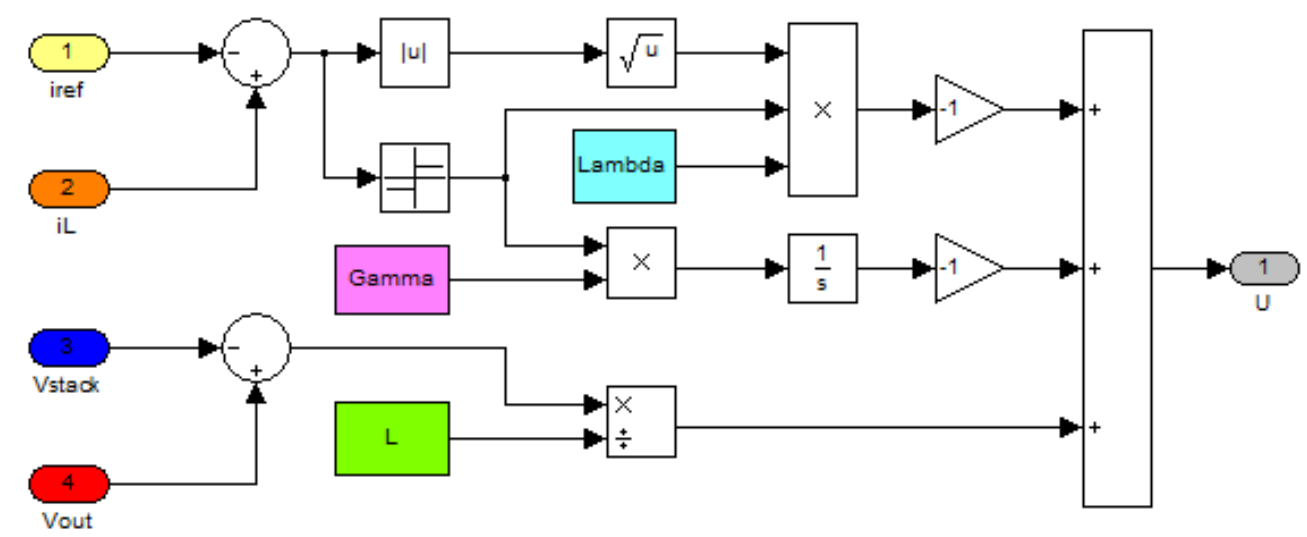

Figure 5. The synoptic diagram of the super-twisting algorithm.

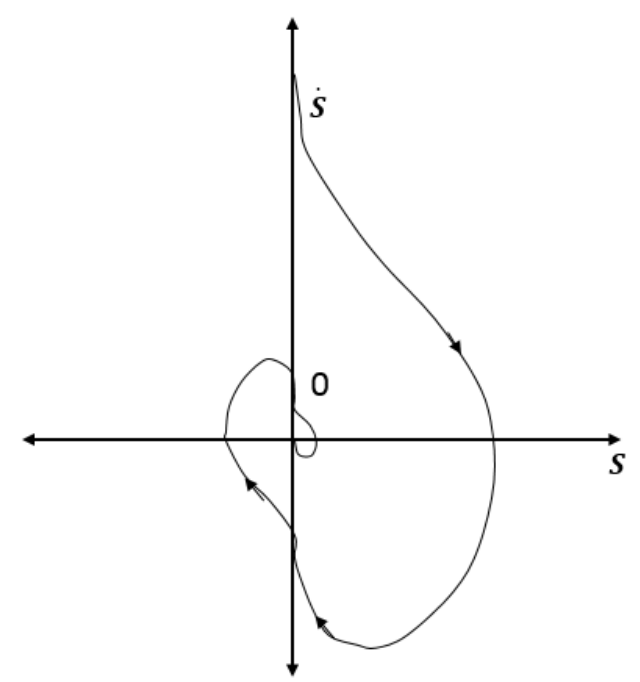

Figure 6. Super-twisting algorithm phase trajectory.

\section{Description of the Experimental System}

The experimental study presented in this section was developed at the laboratory of Automatic Control and System Engineering (ACSE)/ Universidad del Pais Vasco-Euskal Herriko Uniberstsitatea (UPV/EHU). The schematic view of the overall experimental test bench system is shown in Figure 7. The test bench consists of five main parts: a Heliocentris hy-Expert ${ }^{\mathrm{TM}}$ PEMFC Instructor system, a dedicated PC, a DC-DC boost converter, a DSPACE DS1104, and a programmable electronic load. 


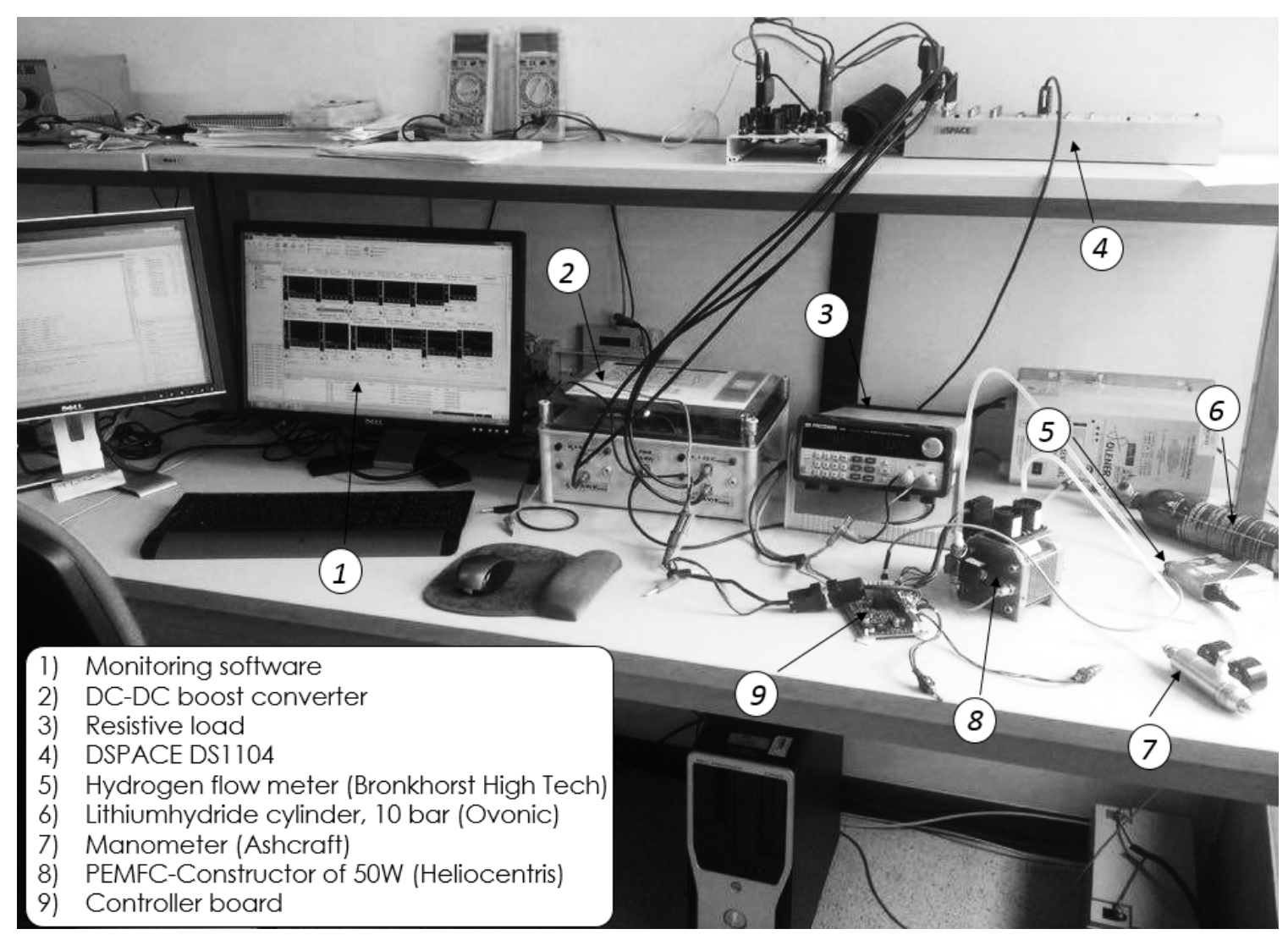

Figure 7. Experimental setup.

The technical specifications of the PEMFC Instructor system are enlisted in Table 1. The used PEMFC is comprised of a stack of 10 identical cells assembled together. Each fabricated cell has an effective membrane area of $25 \mathrm{~cm}^{2}$, a thickness equal to $175 \cdot 10^{-6} \mathrm{~cm}$, and with platinum loadings of $0.3 \mathrm{mg} \cdot \mathrm{Pt} / \mathrm{cm}^{2}$. According to the manufacturer's specifications, the rated output power of the stack is about $40 \mathrm{~W}$ for a rated current of $8 \mathrm{~A}$, and a rated voltage of $5 \mathrm{~V}$. The PEMFC operating voltage ranges from $9 \mathrm{~V}$ (no load) to $5 \mathrm{~V}$ (Full load). At its maximum current condition, where $I_{\max }=10 \mathrm{~A}$, the stack can deliver up to $50 \mathrm{~W}$. The PEMFC operates in a temperature range between $15^{\circ} \mathrm{C}$ and $50{ }^{\circ} \mathrm{C}$. It is fed directly by pure "dead-end-mode" hydrogen ( $99.999 \mathrm{vol} \%$ ) and air (oxygen) without prior humidification. Therefore, a pressure regulator is required to feed the PEMFC with the exact rate of hydrogen that is being consumed. Using the $\mathrm{H}_{2}$ Connection Kits $[1-15] / 0.6$ bar (Manometers Ashcraft), hydrogen can be supplied from the supply tank into the PEMFC at around 0.6 bar (maximum pressure at which the PEMFC could operate). The hydrogen supply tank used in this work is Lithiumhydride Cylinder Ovonics (LCO), Model: 25G25OB /25G555B (Heliocentris). The dimensions of this LCO are $64 \times 305 \mathrm{~mm}$, and it could store $2.391 \mathrm{~kg}$ of hydrogen. In order to refill the cylinder, a $H_{2}$ Connection Kits 200/[1 - 15] bar is used to supply the hydrogen from the refill tank at approximately 10 bar. The flow rate of hydrogen into the PEMFC is measured using the Bronkhorst Gas Flow Meter (BGFM). This latter operates in a measuring range of [10-1000] sml/min and with a precision of $0.8 \%$ of measured value. The required oxygen that will be used in the electrochemical reactions is supplied to the PEMFC as air. Thus, using the cooling fans which are attached to the stack, air is streamed into the cells at atmospheric pressure. The cooling fans not only serve to provide air for the electrochemical reactions, but they also serve to regulate the PEMFC operating temperature through the convective cooling. Therefore, they result in a reduction in controlling the airflow rate and the stack temperature independently. In addition, the implementation of the oxygen cylinder in such systems can be avoided. The speed of the cooling fans can be either controlled manually by 
the operator or automatically by an internal controller. If the fan's control software is adjusted in the position "AUTO" mode, the fans will be controlled automatically according to the PEMFC stack power. In other words, the controller sets the desired fan speed in order to ensure sufficient cooling at all times. Hence, an increase in the PEMFC stack power leads to an increase in the airflow rate (the greater the amount of air is needed for cooling and for the reaction), and so on increasing the fan speed. Additionally, the "AUTO" mode provides enough air in the cathode side in order to decrease as much as possible the mass transport limitations which will result in a reduction in the concentration loss. It should be noted that the airflow used for the convective cooling is significantly more than that used for the electrochemical reactions. Therefore, for systems such as the Heliocentris hy-Expert ${ }^{\mathrm{TM}}$ PEMFC Instructor system, excess airflow is extremely important. On the other hand, if the fan's control software is adjusted in a position other than "AUTO" mode, the fans will be controlled directly by the user. Hence, the fans can be operated manually by selecting the percentage of the speed that can be in a range between $0 \%$ and $100 \%$ of the maximum fan speed. According to the technical specifications provided by the Heliocentris hy-Expert ${ }^{\mathrm{TM}}$ instructor, at full speed (100\%) of 13,000 rpm, each fan could pump around $276 \mathrm{~L} / \mathrm{min}$ of airflow. Therefore, the two fans pump around $552 \mathrm{~L} / \mathrm{min}$ as a maximum amount of airflow that could be supplied to the PEMFC.

Table 1. Fuel cell stack technical data.

\begin{tabular}{|c|c|c|c|}
\hline General & & Electrical & \\
\hline Type & PEM fuel cell stack, 10 cells & Rated voltage & $5.0 \mathrm{VDC}$ \\
\hline Cooling & Air & Rated current & $8.0 \mathrm{~A}$ \\
\hline Fuel & Hydrogen & Rated power output & $40 \mathrm{~W}$ \\
\hline Design & Open cathode & Maximum current & $10 \mathrm{~A}$ \\
\hline $\mathrm{W} \times \mathrm{D} \times \mathrm{H}$ & $120 \times 103 \times 135 \mathrm{~mm}$ & Maximum power output & $50 \mathrm{~W}$ \\
\hline Weight & $1.15 \mathrm{~kg}$ & No-load voltage & $9.0 \mathrm{VDC}$ \\
\hline $\mathrm{H}_{2}$ Flow Meter & \multicolumn{3}{|c|}{$H_{2}$ Connection Kit 15 bar } \\
\hline Measuring range & $10-1000 \mathrm{sml} / \mathrm{min}$ & Inletpressure & $1-15$ bar \\
\hline Precision & $\begin{array}{c}0.8 \% \text { of measured value plus } \\
0.2 \% \text { of full-scale value }\end{array}$ & Outlet pressure & 0.6 bar \\
\hline Thermal & \multicolumn{3}{|c|}{$\mathrm{H}_{2}$ Connection Kit 200 bar } \\
\hline Operating Temp. & $15-50^{\circ} \mathrm{C}$ & Inlet pressure & 200 bar \\
\hline Max.start temp. & $45^{\circ} \mathrm{C}$ & Outlet pressure & $1-15$ bar \\
\hline Fuel & \multicolumn{3}{|c|}{$H_{2}$ Detector } \\
\hline$H_{2}$ purity & $5.0(99.999 \%)$ & Sensor type & Hydrogen $4 \%$ \\
\hline $\mathrm{H}_{2}$ input pressure & $0.4-8$ bar (5.8-11.6 psig) & Measuring principle & 3-electrode sensor \\
\hline $\mathrm{H}_{2}$ consumption & Max. $700 \mathrm{sml} / \mathrm{min}$ (at $0 \mathrm{C}, 1013 \mathrm{bar}$ ) & Standard range & $0.00-4.00 \%$ \\
\hline
\end{tabular}

A proprietary hy-Expert ${ }^{\mathrm{TM}}$ controller board is used for real-time control of the PEMFC system. The controller board represents the distribution center for all data among the PEMFC's complementary instruments including the fans, the $\mathrm{H}_{2}$ flow meter, the temperature sensor, and the software. It has been developed to provide simple operation, ensure the safety of the PEMFC, as well as to protect the stack from over-loads and short circuits. In addition, it allows to supervise and control the PEMFC system through a dedicated PC using monitoring software provided by Heliocentris. Using an integrated RS232 interface, the software allows for initializing/closing the communications, recording and filing of all the data from the PEMFC auxiliaries and sending power commands during the test, as well as enabling the visualization of all of the operating parameters. Thus, parameters such as the electrical characteristics of the PEMFC (voltage (V) and current $(\mathrm{A})$ ), operating temperature $\left({ }^{\circ} \mathrm{C}\right), \mathrm{H}_{2}$ flow rate $(\mathrm{L} / \mathrm{min})$, and fan power $(\%)$ can be recorded and graphically drawn on the software interactive screen.

The DC-DC boost converter used in the test bench was manufactured by TEP-192-Research Group/University of Huelva, Spain. Detailed information about the utilized boost converter is enlisted 
in Table 2. It allows the operator to control the PEMFC system via its metal-oxide-semiconductor field-effect transistor (MOSFET) switching input $(20 \mathrm{kHz})$ which comes directly from the PWM card of the dSpace. In addition, it is equipped with four sensors: two sensors are used to measure the input and output current, and the others are used to measure the input and output voltage. These sensors are calibrated in order to obtain analog signals between 0 and $\pm 10 \mathrm{~V}$ as accepted by the analog-to-digital converter (ADC) block of the dSpace. In addition, low pass filters were utilized in the measuring units in order to remove the undesired high-frequency noise.

Table 2. Technical specifications of the DC-DC boost converter.

\begin{tabular}{cc}
\hline Parameter & Description \\
\hline Schottky diode & 2xMURF1560 GT, $0.4 \mathrm{~V}, 10 \mathrm{~A}, 600 \mathrm{~V}, 15 \mathrm{~A} / 150^{\circ} \mathrm{C}$ \\
Capacitance $C_{0}$ and $C_{1}$ & 2xTK Series, $1500 \mu \mathrm{F}$ and $3000 \mu \mathrm{F}$ \\
Inductance L & 6xPCV-2-564-08 $560 / 6 \mu \mathrm{H}, 7 \mathrm{~A}, 42 \mathrm{~m} \Omega$ \\
I GBT & 1xHGT40N60B3, $600 \mathrm{~V}, 40 \mathrm{~A}, 1.5 \mathrm{~V}, 150^{\circ} \mathrm{C}$ \\
Switching frequency & $20 \mathrm{KHz}$ \\
Maximum input/output voltage & $V_{\text {in } \max }=60 \mathrm{~V}, V_{\text {out }}$ max $=200 \mathrm{~V}$ \\
Maximum input/output current & $I_{\text {in }} \max =20 \mathrm{~A}, I_{\text {out }}$ max $=20 \mathrm{~A}$ \\
\hline
\end{tabular}

The dSpace used in this work is DS1104 real-time controller board. It has a MPC8240 processor (PowerPC 603e core; $250 \mathrm{MHz}$ CPU), 64-bit floating-point processor, internal cache of $32 \mathrm{MB}$ SDRAM Global memories, slave DSP subsystem DSP/TMS320F240 from Texas Instruments Company (Texas, TIC, United States), 8 MB Flash memories, 8 ADC channels, eight digital-to-analog converter (DAC) channels, and five timer interrupts. The dSpace is a powerful tool that is able to modify the controller parameters in real time, as well as to monitor the real processes while operating an experiment. Accordingly, using its Real-Time Interface (RTI), it enables the linkage between the hardware system and the MATLAB/Simulink software (R2015a-MATLAB/Simulink 8.5, MathWorks). In detail, the obtained signals from the sensors are linked to the dSpace via the ADC block and accordingly, they will be read by MATLAB/Simulink using the communication library element DS1104ADC - CX. In this work, four channels are used to read the signals from the ADC: DS1104ADC - C5 is configured to read $V_{\text {stack }}, D S 1104 A D C-C 6$ is configured to read $I_{\text {stack }}, D S 1104 A D C-C 7$ is configured to read $V_{\text {out }}, D S 1104 A D C-C 8$ is configured to read $I_{\text {out }}$. As shown in Figure 8, the RTI allows the operator to design and implement a digital controller simply by drawing the needed block diagrams (available in the library) on the graphical interface of MATLAB/Simulink.

By compiling the model, the RTI generates and downloads a specific real-time C code for the dSPACE. The standard PWM pulses will be generated using the PWM library block DS1104SL - DSP - PWM and then they will be linked to the MOSFET of the boost converter via the digital-to-analog converter (DAC) block. Meanwhile, the signals came from the channels will be sent to the MATLAB base workspace using "To workspace" block. The evolution of each signal will be screened online in the PC using "Controldesk" monitoring software which read the signals data from the workspace.

The system is connected with a BK-Precision-1788B programmable single-output DC power supply, which provides a programmable electronic load with a resistance in the range of $0.1-1000 \Omega$. The load being made by the Fotronic Corporation Company (Washington, FCC, USA), and it has an operating range between $0 \mathrm{~W}$ and $120 \mathrm{~W}$, with a maximum input voltage of $115 \mathrm{~V} / 47 \mathrm{~Hz}$. It can be programmed through PV-1785B-1788 software. 


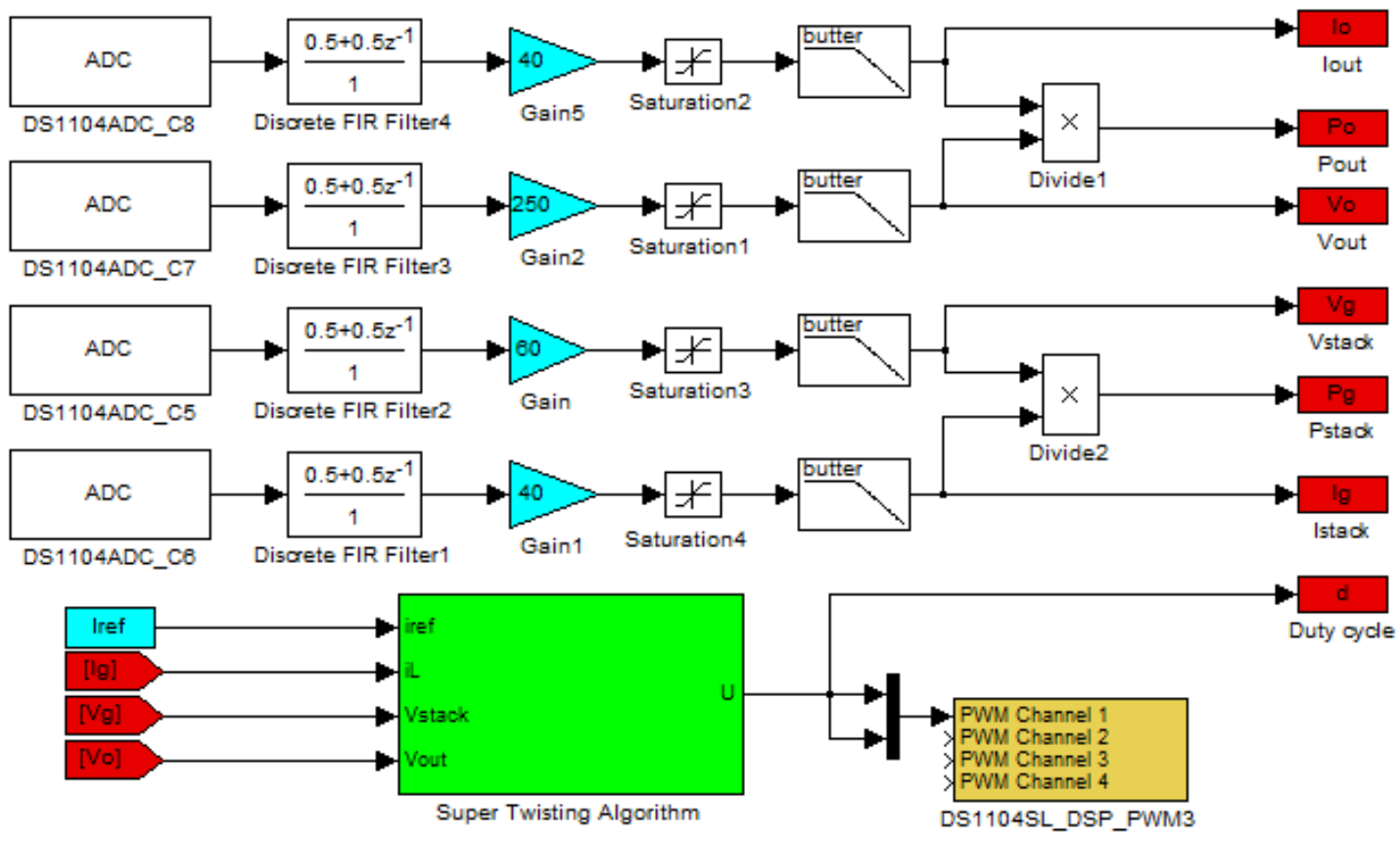

Figure 8. Control design in MATLAB/Simulink software.

\section{Results and Discussion}

The characteristics of Heliocentris hy-Expert ${ }^{\mathrm{TM}}$ PEMFC 50 Instructor system are obtained by connecting the PEMFC stack directly to the load. To clarify the process, load current $\left(I_{\text {out }}\right)$ is increased from 0.1 to $4.6 \mathrm{~A}$ in steps of $0.5 \mathrm{~A}$ for each $10 \mathrm{~s}$. In addition, in order to get precise points, steps of $0.1 \mathrm{~A}$ are used at the beginning and at the end of the measurements. The current $I_{\text {out }}$ and voltage $V_{\text {out }}$ are measured via the laboratory measuring instrument "DT9205A" to validate the theoretical work which presented in [31]. It is important to know that, during the last four years, many tests have been done on the PEMFC stack which occurred a degradation in the cells. This latter caused a decreasing in the fuel cell performances. However, since the main aim of this work is to validate the performance of the STA, a decreasing in the efficiency of the fuel cell will not be a big issue. The experimental polarization curves Current-Voltage (I-V) and Current-Power (I-P) for sundry operating temperatures are presented in Figure 9.

The open circuit voltage of the PEM fuel cell stack is in the range of 8-10 V. The drop voltage at the beginning and end of the curves shown in this figure are due to activation and concentration losses, respectively. Actually, the latter does not appear very well due to the integrated controller board which closes the system in order to protect the stack from the damage. The voltage drop in the middle of the curves (which is approximately linear) is due to the ohmic loss in the fuel cell. The polarization curves shown in Figure 9 indicate that the PEMFC stack performance is ameliorated with rising temperature from 20 to $38^{\circ} \mathrm{C}$, and diminished for higher temperatures $\left(T>45^{\circ} \mathrm{C}\right)$. In other words, for a given current $I_{\text {out }}$, it is apparent that, by increasing the operating temperature, the PEMFC shows better performance. In terms of measured voltage and power, the performance improvement of the PEMFC stack between 20 and $38^{\circ} \mathrm{C}$ can be explained by the augmentation in the membrane conductivity, as well as to the increased exchange current density at higher degrees of temperature, which diminishes the activation losses. However, if the operating temperature is high enough, the membrane conductivity decreases as a consequence of the lack in relative humidity in the electrolyte membrane. Therefore, a diminution in the stack voltage is observed when $T>45^{\circ} \mathrm{C}$. In comparison with the theoretical description which is given in [31], it is clear that the efficiency of the real PEMFC is lower than the estimated theoretical efficiency. In addition, it is noticeable that the influence of temperature variations is greater than what 
is obtained in the theoretical work. This is due to the variations in some parameters that are used as constants in the theoretical model. However, practical results that are shown in Figure 9 validate that the efficiency of the fuel cell can be ameliorated by increasing its temperature. Additionally, it is obvious that the output power is improved by rising the current $I_{o u t}$ from $0.1 \mathrm{~A}$ to $4.6 \mathrm{~A}$ and the obtained curves have the same trends with the simulation results.
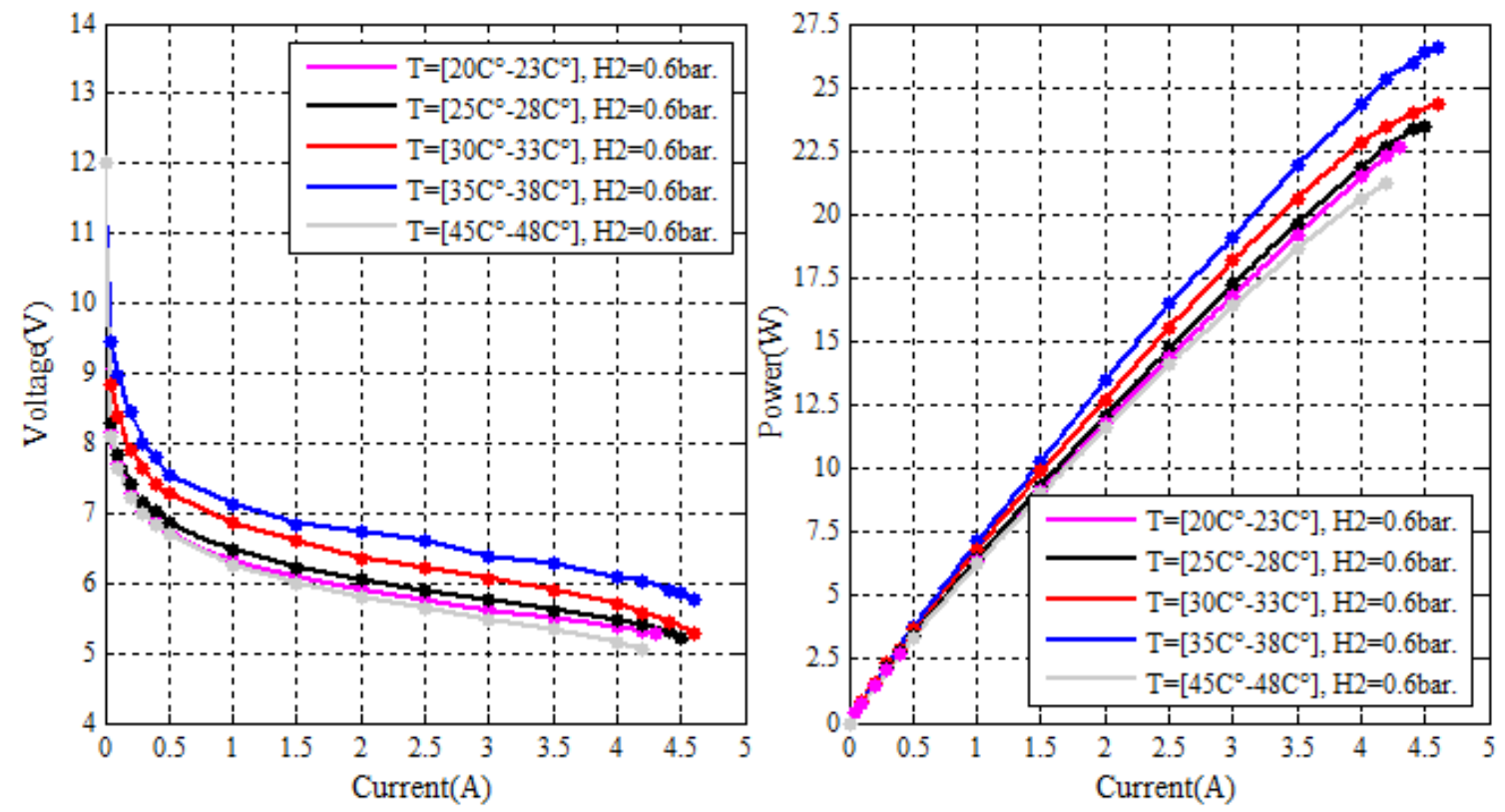

Figure 9. Experimental polarization curves for various operating temperatures $\left(20-48^{\circ} \mathrm{C}\right)$.

Usually, in fuel cell systems, the control processes are used to keep the system functioning at the maximum power point (MPP). However, in accordance with the obtained I-V and I-P characteristics which were presented in Figure 9, it is noticeable that attaining the MPP could be an intractable task. This is due to the safety system which turns off the fuel cell when its power is close to the MPP. Hence, although the safety system protects the stack from the damage, it also makes its operation very sensitive around the MPP. For this reason, an operation zone as presented in Figure 10 is established to provide at least $72 \%$ of the maximum power produced by the fuel cell. In fact, the MPP could be in the range of 2-8 W more than the operation zone. This range is used taking into account the controllers' behavior (chattering phenomenon, overshoots when load changing) in order to guarantee the continuation of the fuel cell operating process.

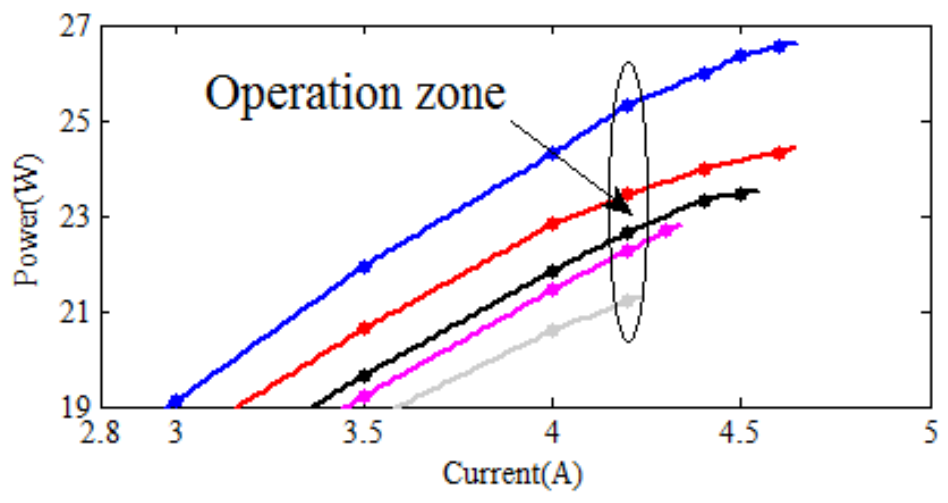

Figure 10. Fuel cell operation zone. 
In order to find out the performance of super twisting algorithm (STA) and its features over traditional 1-order SMC, load variation from $20 \Omega$ to $50 \Omega$ is applied at $\mathrm{t}=25 \mathrm{~s}$ and from $50 \Omega$ to $20 \Omega$ is applied at $\mathrm{t}=45 \mathrm{~s}$. The controllers' coefficients used in this work are enlisted in Table 3.

Table 3. Controllers' coefficients.

\begin{tabular}{cc}
\hline Sliding Mode Controller & Super-Twisting Algorithm \\
\hline$\kappa=0.01$ & $\lambda=0.01, \gamma=0.1$ \\
\hline
\end{tabular}

Figures 11-14 show respectively the duty cycle signal, the PEMFC output signals (voltage, current, and power), and finally the boost converter output signals (voltage, current, and power). These figures show the behaviour of the SMC and STA to track and maintain the system functioning at the efficient operation zone. In general, both of the controllers show global stability and satisfactory tracking results so as to keep the system at the operation zone. However, it is clearly shown that the STA has a high capability to decrease the chattering effect that occurs by the SMC. Consequently, these figures validate the results obtained in the previous simulations that were presented in [31]. On the other hand, Figures 11-14 also show the behaviour of the SMC and STA when they are confronted by load variations at $\mathrm{t}=25 \mathrm{~s}$ and $\mathrm{t}=45 \mathrm{~s}$.

The duty cycle signals generated by the controllers are shown in Figure 11.

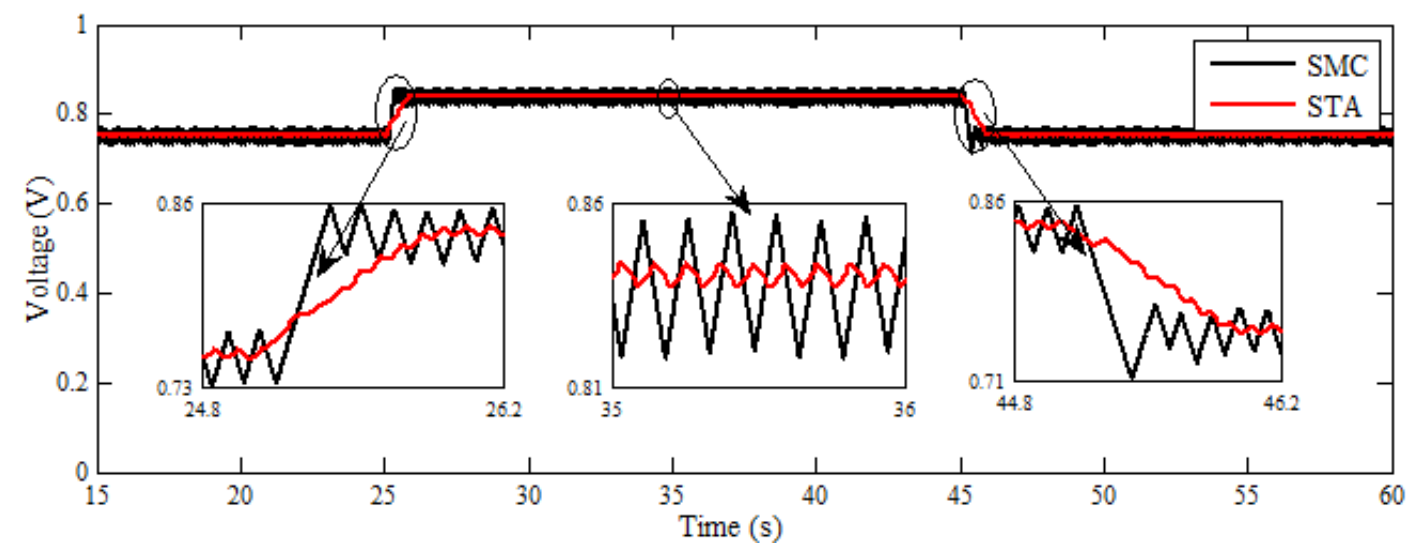

Figure 11. Duty cycle signal.

As can be seen from this figure, the controllers effectively control the duty cycle so as to obtain constant current with fast response time and no drift. It is important to note that, in comparison with the previous simulation work, some noises occurred in the obtained experimental signals. However, this is resulting from the effect of time-delay in the control signal, as well as the parasite signals which came from hardware components.

The fuel cell output voltage and current signals are shown in Figure 12. This last illustrates the behavior of the SMC and STA when experiencing load variations at $t=25 \mathrm{~s}$ and $\mathrm{t}=45 \mathrm{~s}$. According to this figure, it is clear that both of the controllers manifest high robustness even when large load variations is accrued (30 $\Omega$ ). Thus, by varying the load resistance from $20 \Omega$ to $50 \Omega$ and from $50 \Omega$ to $20 \Omega$, the SMC manifests an overshoot and undershoot voltage of $0.6 \mathrm{~V}$ and $0.9 \mathrm{~V}$, as well as an undershoot and overshoot current of $1.2 \mathrm{~A}$ and $2.6 \mathrm{~A}$, respectively. For the same variations, the STA manifests an overshoot and undershoot voltage of $0.9 \mathrm{~V}$ and $1.6 \mathrm{~V}$ as well as an undershoot and overshoot current of $1.8 \mathrm{~A}$ and $3.9 \mathrm{~A}$, respectively. Therefore, despite the large load variations, only small overshoots are accrued. In addition, these overshoots only appear for a short period of time (response time $\leq 1 \mathrm{~s}$ ), and they swiftly converge to the steady-state value. Figure 12 also shows that, using SMC, the fuel cell output DC voltage oscillations can reach about $12 \%$ while the oscillations of 
the output current is over 35\%. These oscillations introduce small deviations from the operating point and especially they may even cause irreversible damage to the fuel cell. On the other side, the fuel cell output DC voltage oscillations using STA is only about $0.26 \%$ and the oscillations of the output current is less than $7 \%$. Therefore, compared to the SMC, high accuracy, robustness, and good dynamic behavior are obtained even with large load variations.

The fuel cell output power trajectories are presented in Figure 13. According to these trajectories, it is obvious that the operation zone is attained with swift speed and stability of the closed-loop system. On the other hand, it is clearly shown that the chattering phenomenon is almost eliminated by using the STA. Indeed, the chattering magnitude using the SMC varies approximately from $20.5 \mathrm{~W}$ to $27 \mathrm{~W}$, while it only varies from $23.3 \mathrm{~W}$ to $23.9 \mathrm{~W}$ using the STA. Accordingly, it is proven that the proposed STA has succeeded at reducing about $91 \%$ of the chattering effect, which will improve, as a consequence, the fuel cell lifetime.

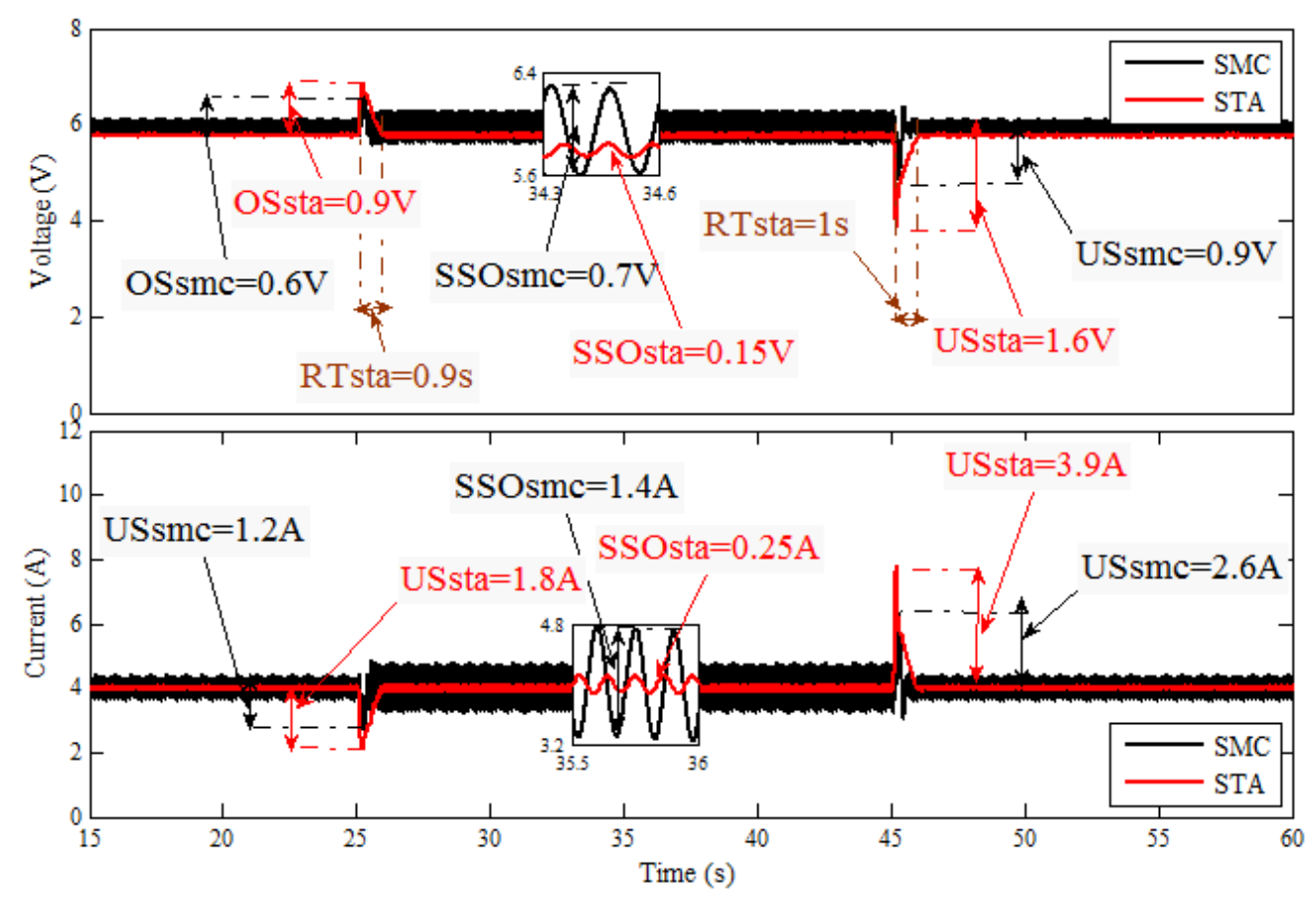

Figure 12. PEM fuel cell stack voltage and current.

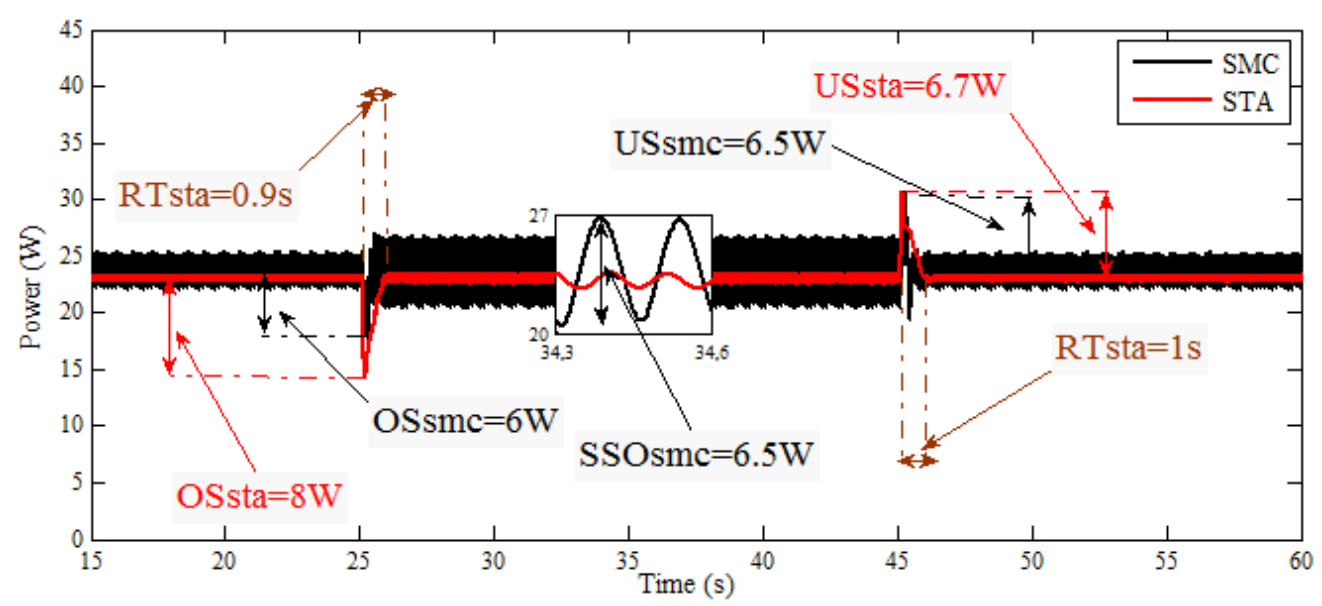

Figure 13. PEMFC stack power. 
The behaviour of the output voltage, current, and power of the DC-DC boost converter under load variations are presented in Figure 14. According to this figure, it is clear that, despite the heavy loading conditions, the STA manifests gradual and smooth movement to the desired voltage at which the system will work in the operation zone. Moreover, high performances such as low response time (less than $1 \mathrm{~s}$ ), robustness, great precision, as well as excellent dynamic behavior are achieved.

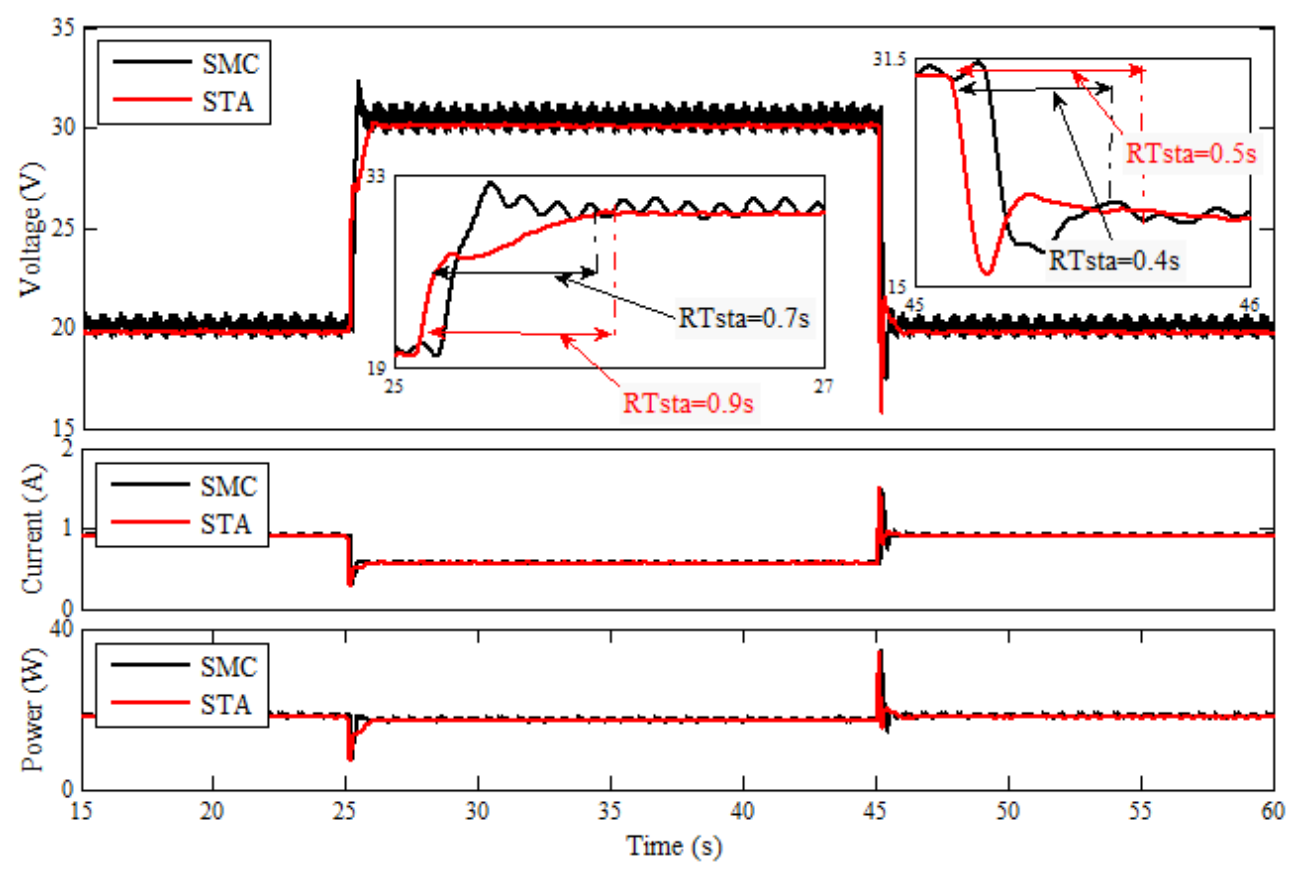

Figure 14. Boost converter output voltage, current, and power.

Based on the results obtained in this section, it is clearly manifested that this experimental work shows the same results with that obtained in the previous simulation work. Accordingly, the capability of the STA to reduce the chattering effect, while attaining high performances, is clearly proven.

\section{Conclusions}

A 50-W PEMFC Instructor system feeding load resistance through a step-up DC-DC power converter has been experimentally studied in this work. The hardware system components, including the fuel cell with its auxiliaries, the power converter, the control system and the data acquisition, have been installed and conducted together with the dSPACE 1104 controller board. The control algorithms have been designed in MATLAB/Simulink environment and connected to the dSPACE-card using the DS1104 linkage blocks.

The temperature effect on the PEMFC performance has been studied. The obtained I-V and I-P characteristics of the PEMFC for different operating temperatures proves that the PEMFC performance is improved by increasing its operating temperature from 20 to $38^{\circ} \mathrm{C}$. Alternatively, the fuel cell performance worsens at higher temperatures as the electrolyte membranes can be dried.

Therefore, in order to bring the system to an efficient power point, an operation zone is established to provide at least $72 \%$ of the maximum power produced by the fuel cell. Successful implementation of SMC and STA in an actual fuel cell has experimentally demonstrated the effectiveness of these control solutions to bring the system to the operation zone. However, high performances such as low response time, robustness, great precision, simple implementation, as well as excellent dynamic behavior, are attained using the proposed STA. Therefore, it is proven that the STA ensures all the fundamental properties of its traditional 1-order SMC, in addition to providing chattering reduction of $91 \%$, which will ameliorate, as a consequence, the fuel cell lifetime. 
Since the calculation of an optimal operation zone is significantly important for systems such as Heliocentris hy-Expert ${ }^{\mathrm{TM}}$ PEMFC, this paper paves the way for further advanced research on this topic.

Author Contributions: Data curation, M.D.; Formal analysis, M.D.; Investigation, M.D.; Methodology, M.D.; Resources, O.B.; Software, M.D.; Supervision, O.B. and L.S.; Validation, M.D., O.B. and J.A.R.-H.; Visualization, M.D.; Writing—original draft, M.D. Writing—review and editing, M.D. and O.B.

Funding: This research was funded by the UPV/EHU PPGA18/04 and by the Basque Government through the project ETORTEK KK-2017/00033.

Acknowledgments: The authors would like to acknowledge the UPV/EHU and the Basque Government for supporting this work through the projects PPGA18/04 and ETORTEK KK-2017/00033. The authors also would like to express their gratitude to the Tunisian Government for supporting this work through the research unit UR11ES82.

Conflicts of Interest: The authors declare no conflict of interest.

\section{Abbreviations}

The following abbreviations are used in this manuscript:

SMC Sliding Mode Control

PEMFC Proton Exchange Membrane Fuel Cell

STA Super Twising Algorithm

RES Renewable Energy Sources

PWM Pulse Width Modulation

PI Proportional-Integral

PID Proportional-Integral Derivative

GA Genetic Algorithm

LQR Linear Quadratic Regulator

FLC Fuzzy Logic Controller

DEC Dynamic Evolution Control

RMSE Root Mean Square Error

RBFNN Radial Basis Function Neural Network

NSGA Non-dominated Sorting Genetic Algorithm

HHV Higher Heating Value

CCM Continuous-Conduction-Mode

DCM Discontinuous-Conduction-Mode

PC Personal Computer

LCO Lithiumhydride Cylinder Ovonics

BGFM Bronkhorst Gas Flow Meter

ADC Analog to Digital Converter

DAC Digital to Analog Converter

TIC Texas Instruments Company

RTI Real-Time Interface

MPP Maximum Power Point

MOSFET Metal-Oxide-Semiconductor Field-Effect Transistor

UPV Universidad del Pais Vasco

EHU Euskal Herriko Uniberstsitatea

\section{References}

1. Romero-Fiances, I.; Muñoz-Cerón, E.; Espinoza-Paredes, R.; Nofuentes, G.; de la Casa, J. Analysis of the Performance of Various PV Module Technologies in Peru. Energies 2019, 12, 186. doi:10.3390/en12010186. [CrossRef]

2. Bocca, A.; Bergamasco, L.; Fasano, M.; Bottaccioli, L.; Chiavazzo, E.; Macii, A.; Asinari, P. Multiple-Regression Method for Fast Estimation of Solar Irradiation and Photovoltaic Energy Potentials over Europe and Africa. Energies 2018, 11, 3477. doi:10.3390/en11123477. [CrossRef] 
3. Zeraatpisheh, M.; Arababadi, R.; Saffari Pour, M. Economic Analysis for Residential Solar PV Systems Based on Different Demand Charge Tariffs. Energies 2018, 11, 3271. doi:10.3390/en11123271. [CrossRef]

4. Möllerström, E. Wind Turbines from the Swedish Wind Energy Program and the Subsequent Commercialization Attempts-A Historical Review. Energies 2019, 12, 690. doi:10.3390/en12040690. [CrossRef]

5. Baloch, M.H.; Ishak, D.; Chaudary, S.T.; Ali, B.; Memon, A.A.; Jumani, T.A. Wind Power Integration: An Experimental Investigation for Powering Local Communities. Energies 2019, 12, 621. doi:10.3390/en12040621. [CrossRef]

6. Rosli, R.; Sulong, A.; Daud, W.; Zulkifley, M.; Husaini, T.; Rosli, M.; Majlan, E.; Haque, M. A review of high-temperature proton exchange membrane fuel cell (HT-PEMFC) system. Int. J. Hydrog. Energy 2016, 42, 9293-9314. doi:10.1016/j.ijhydene.2016.06.211. [CrossRef]

7. Simari, C.; Potsi, G.; Policicchio, A.; Perrotta, I.; Nicotera, I. Clay-Carbon Nanotubes Hybrid Materials for Nanocomposite Membranes: Advantages of Branched Structure for Proton Transport under Low Humidity Conditions in PEMFCs. J. Phys. Chem. C 2016, 120, 2574-2584. doi:10.1021/acs.jpcc.5b11871. [CrossRef]

8. Liu, Z.; Kendall, K.; Yan, X. China Progress on Renewable Energy Vehicles: Fuel Cells, Hydrogen and Battery Hybrid Vehicles. Energies 2018, 12, 54. doi:10.3390/en12010054. [CrossRef]

9. Derbeli, M.; Barambones, O.; Sbita, L. A Robust Maximum Power Point Tracking Control Method for a PEM Fuel Cell Power System. Appl. Sci. 2018, 8, 2449. doi:10.3390/app8122449. [CrossRef]

10. Byun, S.J.; Wang, Z.; Son, J.; Kwak, D.K.; Kwon, Y.C. Experimental study on improvement of performance by wave form cathode channels in a PEM fuel cell. Energies 2018, 11, 319. doi:10.3390/en11020319. [CrossRef]

11. Luta, D.N.; Raji, A.K. Fuzzy Rule-Based and Particle Swarm Optimisation MPPT Techniques for a Fuel Cell Stack. Energies 2019, 12, 936. doi:10.3390/en12050936. [CrossRef]

12. Barrero-González, F.; Pires, V.F.; Sousa, J.L.; Martins, J.F.; Milanés-Montero, M.I.; González-Romera, E.; Romero-Cadaval, E. Photovoltaic Power Converter Management in Unbalanced Low Voltage Networks with Ancillary Services Support. Energies 2019, 12, 972. doi:10.3390/en12060972. [CrossRef]

13. Song, S.; Li, W.; Ni, K.; Xu, H.; Hu, Y.; Si, J. Modular Multi-Port Ultra-High Power Level Power Converter Integrated with Energy Storage for High Voltage Direct Current (HVDC) Transmission. Energies 2018, 11, 2711. doi:10.3390/en11102711. [CrossRef]

14. Yasin, A.; Ashraf, M.; Bhatti, A. Fixed frequency sliding mode control of power converters for improved dynamic response in DC micro-grids. Energies 2018, 11, 2799. doi:10.3390/en11102799. [CrossRef]

15. Muñoz, J.G.; Gallo, G.; Angulo, F.; Osorio, G. Slope Compensation Design for a Peak Current-Mode Controlled Boost-Flyback Converter. Energies 2018, 11, 3000. doi:10.3390/en11113000. [CrossRef]

16. Luo, F.L.; Ye, H. Advanced dc/dc Converters; CRC Press: Boca Raton, FL, USA, 2016. doi:10.1201/9781315393780.

17. Naik, M.V.; Samuel, P. Analysis of ripple current, power losses and high efficiency of DC-DC converters for fuel cell power generating systems. Renew. Sustain. Energy Rev. 2016, 59, 1080-1088. doi:10.1016/j.rser.2016.01.029. [CrossRef]

18. Andrade, A.M.; Mattos, E.; Schuch, L.; Hey, H.L.; Martins, M.L. Synthesis and Comparative Analysis of Very High Step-Up DC-DC Converters adopting Coupled Inductor and Voltage Multiplier Cells. IEEE Trans. Power Electron. 2017, 33, 5880-5897. doi:10.1109/TPEL.2017.2742900. [CrossRef]

19. Choe, S.Y.; Lee, J.G.; Ahn, J.W.; Baek, S.H. Integrated modeling and control of a PEM fuel cell power system with a PWM DC/DC converter. J. Power Sources 2007, 164, 614-623. doi:10.1016/j.jpowsour.2006.10.082. [CrossRef]

20. Andujar, J.; Segura, F.; Vasallo, M. A suitable model plant for control of the set fuel cell- DC/DC converter. Renew. Energy 2008, 33, 813-826. doi:10.1016/j.renene.2007.04.013. [CrossRef]

21. Derbeli, M.; Farhat, M.; Barambones, O.; Sbita, L. Control of Proton Exchange Membrane Fuel Cell (PEMFC) power system using PI controller. In Proceedings of the 2017 International Conference on Green Energy Conversion Systems (GECS), Hammamet, Tunisia, 23-25 March 2017; pp. 1-5. doi:10.1109/GECS.2017.8066175. [CrossRef]

22. Habib, M.; Khoucha, F.; Harrag, A. GA-based robust LQR controller for interleaved boost DC-DC converter improving fuel cell voltage regulation. Electr. Power Syst. Res. 2017, 152, 438-456. doi:10.1016/j.epsr.2017.08.004. [CrossRef]

23. Huang, S.R.; Lin, C.Y.; Wu, C.C.; Yang, S.J. The application of fuzzy controller for fuel cell generating studies. Int. J. Hydrog. Energy 2008, 33, 5205-5217. doi:10.1016/j.ijhydene.2008.05.018. [CrossRef] 
24. Harrag, A.; Messalti, S. How fuzzy logic can improve PEM fuel cell MPPT performances? Int. J. Hydrog. Energy 2018, 43, 537-550. doi:10.1016/j.ijhydene.2017.04.093. [CrossRef]

25. Kim, Y.; Kang, S. Time delay control for fuel cells with bidirectional DC/DC converter and battery. Int. J. Hydrog. Energy 2010, 35, 8792-8803. doi:10.1016/j.ijhydene.2010.05.022. [CrossRef]

26. Samosir, A.S.; Yatim, A.H.M. Implementation of dynamic evolution control of bidirectional DC-DC converter for interfacing ultracapacitor energy storage to fuel-cell system. IEEE Trans. Ind. Electron. 2010, 57, 3468-3473. doi:10.1109/TIE.2009.2039458. [CrossRef]

27. Kuo, J.K.; Wang, C.F. An integrated simulation model for PEM fuel cell power systems with a buck DC-DC converter. Int. J. Hydrog. Energy 2011, 36, 11846-11855. doi:10.1016/j.ijhydene.2011.05.107. [CrossRef]

28. Wang, F.C.; Guo, Y.F. Robustness analyses of PEMFC systems on the production line. Int. J. Hydrog. Energy 2015, 40, 1959-1966. doi:10.1016/j.ijhydene.2014.11.146. [CrossRef]

29. Rezazadeh, A.; Askarzadeh, A.; Sedighizadeh, M. Adaptive inverse control of proton exchange membrane fuel cell using RBF neural network. Int. J. Electrochem. Sci. 2011, 6, 3105-3117.

30. Abaspour, A.; Parsa, N.T.; Sadeghi, M. A new feedback Linearization-NSGA-II based control design for PEM fuel cell. Int. J. Comput. Appl. 2014, 97, 25-32. [CrossRef]

31. Derbeli, M.; Farhat, M.; Barambones, O.; Sbita, L. Control of PEM fuel cell power system using sliding mode and super-twisting algorithms. Int. J. Hydrog. Energy 2017, 42, 8833-8844. doi:10.1016/j.ijhydene.2016.06.103. [CrossRef]

32. Derbeli, M.; Farhat, M.; Barambones, O.; Sbita, L. A robust MPP tracker based on backstepping algorithm for Proton Exchange Membrane Fuel Cell power system. In Proceedings of the 2017 11th IEEE International Conference on Compatibility, Power Electronics and Power Engineering (CPE-POWERENG), Cadiz, Spain, 4-6 April 2017; pp. 424-429. doi:10.1109/CPE.2017.7915209. [CrossRef]

33. Li, C.; Sallee, A.; Zhang, X.; Kumar, S. Electrochemical Hydrogenation of Acetone to Produce Isopropanol Using a Polymer Electrolyte Membrane Reactor. Energies 2018, 11, 2691. doi:10.3390/en11102691. [CrossRef]

34. Bai, B.; Chen, Y.T. Simulation of the Oxygen Reduction Reaction (ORR) Inside the Cathode Catalyst Layer (CCL) of Proton Exchange Membrane Fuel Cells Using the Kinetic Monte Carlo Method. Energies 2018, 11, 2529. doi:10.3390/en11102529. [CrossRef]

35. Zhang, X.; Higier, A.; Zhang, X.; Liu, H. Experimental Studies of Effect of Land Width in PEM Fuel Cells with Serpentine Flow Field and Carbon Cloth. Energies 2019, 12, 471. doi:10.3390/en12030471. [CrossRef]

36. Bahrebar, S.; Blaabjerg, F.; Wang, H.; Vafamand, N.; Khooban, M.H.; Rastayesh, S.; Zhou, D. A novel type-2 fuzzy logic for improved risk analysis of proton exchange membrane fuel cells in marine power systems application. Energies 2018, 11, 721. doi:10.3390/en11040721. [CrossRef]

37. Derbeli, M.; Sbita, L.; Farhat, M.; Barambones, O. Proton exchange membrane fuel cell-A smart drive algorithm. In Proceedings of the 2017 International Conference on Green Energy Conversion Systems (GECS), Hammamet, Tunisia, 23-25 March 2017; pp. 1-5. doi:10.1109/GECS.2017.8066167. [CrossRef]

38. EG\&G Technical Services, Inc. Fuel Cell Handbook; U.S. Department of Energy, Office of Fossil Energy, National Energy Technology Laboratory, Science Application International Corporation: Morgantown, WV, USA, 2002.

39. Larminie, J.; Dicks, A. Fuel Cell Systems Explained; John Willey \& Sons, Ltd.: Hoboken, NJ, USA, 2000.

40. Mohan, N.; Mohan, T.M. Power Electronics; John Wiley \& Sons: New York, NY, USA, 1995; Volume 3.

41. Derbeli, M.; Sbita, L.; Farhat, M.; Barambones, O. PEM fuel cell green energy generation-SMC efficiency optimization. In Proceedings of the 2017 International Conference on Green Energy Conversion Systems (GECS), Hammamet, Tunisia, 23-25 March 2017; pp. 1-5. doi:10.1109/GECS.2017.8066168. [CrossRef]

42. Levant, A. Principles of 2-sliding mode design. Automatica 2007, 43, 576-586. doi:10.1016/j.automatica.2006.10.008. [CrossRef]

43. Levant, A. Sliding order and sliding accuracy in sliding mode control. Int. J. Control 1993, 58, 1247-1263. doi:10.1080/00207179308923053. [CrossRef]

44. Slotine, J.J.E.; Li, W. Applied Nonlinear Control; Prentice Hall Englewood Cliffs: New York, NY, USA, 1991; Volume 199. 
45. Emelyanov, S. High order sliding modes in control systems. Differ. Equ. 1993, 29, 1627-1647. [CrossRef]

(C) 2019 by the authors. Licensee MDPI, Basel, Switzerland. This article is an open access article distributed under the terms and conditions of the Creative Commons Attribution (CC BY) license (http:/ / creativecommons.org/licenses/by/4.0/). 